ANDRÁS L. PAP*

\title{
Criminal Justice and Ethnic Data Collection in Hungary ${ }^{1}$
}

\begin{abstract}
The paper analyzes ethnic data collection pertaining to criminal justice in Hungary. It shows that Hungary's approach to resist ethnic data collection by law enforcement authorities is not a good policy and it causes severe constitutional problems in other, noncriminal legal circumstances, where ethnic data is used in the context of additional rights and affirmative protection provided for ethno-national minorities. The paper follows a twofold analysis. First, it sets forth general problems relating to ethnic data collection, including a brief analysis of a uniquely Hungarian constitutional institution, the minority self-government structure. The focus of scrutiny then shifts to the criminal justice system, in particular the analysis of policing of racially motivated crime, and the question of police ethnic profiling.
\end{abstract}

Keywords: Ethnic data collection, criminal justice, minorities, minority self-governments, "ethno-corruption", racially motivated crime, ethnic profiling, police, stop and search.

\section{Introduction}

This paper will analyze ethnic data collection pertaining to criminal justice in Hungary. In most projects scrutinizing ethnic data collection practices, there is always a hidden suggestion that ethnic classification by law enforcement authorities inevitably invokes suspicion about ethnic profiling or disparate treatment based on ethnic identity. This project will not be an exception to this. The paper will show that although Hungary's approach to resist ethnic data collection by law enforcement authorities seems superficially appealing, in fact, it is not a good policy. It will be demonstrated that Hungary is one of the (many) countries in which extensive legal restrictions on the collection of nonanonymous data concerning ethnic, national or religious identity have prompted law enforcement authorities to simply deny that ethnicity is of significance in their actions. This, however, is no guarantee that there are no misuses of police

"Research Fellow, Institute for Legal Studies of the Hungarian Academy of Sciences; Professor of Law, Kodolányi College, Székesfehérvár, Hungary, H-1014 Budapest, Országház u. 30. E-mail: papandras@mtaki.hu

${ }^{1}$ Special thanks to Zsofia Zvolenszky. 
power or that ethnic profiling does not exist. The only effect of such restrictive policies is that claims relating to indirect discrimination become enormously difficult to prove. The paper will also show that in Hungary, such a restrictive approach to ethno-national data classification also causes severe constitutional problems in other, non-criminal legal circumstances, where ethnic data is used in the context of additional rights and affirmative protection provided for ethnonational minorities.

Traditionally, within Hungary, law enforcement methods based on ethnic selection have affected the Roma minority rather than minute other ethnic or racial communities. As we shall see, the authorities have virtually unlimited discretion when it comes to stops and searches, and as a result, the possibility for misuse of power remains unhindered.

The paper will therefore follow a twofold analysis. First, it will set forth general problems relating to the above described approach to ethnic data collection. This will include a brief analysis of some controversies and challenges to a uniquely Hungarian constitutional institution, the minority self-government structure. The focus of scrutiny then shifts to the criminal justice system, about which the paper will show that the denial of ethnic data collection is not a good policy. This thesis will be supported by two examples: first, the analysis of policing of racially motivated crime, and second, the question of police ethnic profiling. In reference to the first question, it will be argued that law enforcement agents, as well as prosecutors and courts, are very reluctant to recognize racial motivation in violent and non-violent crimes, and will only qualify such criminal activity as nuisance, assault or mischief. Following this, by turning to a more detailed analysis of ethnic profiling, the paper will first describe the actual procedure involved in police ethnic data collection. The paper will conclude by restating that prohibiting the official recognition and collection of data on ethnicity (that is nevertheless present and taken into consideration) by criminal justice authorities is a potentially ethnically discriminatory practice.

\section{When Is a Minority a Minority?}

\section{Target groups}

In the Hungarian legal and political jargon the terms "ethnic" and "national" minorities (and features) are used instead of "racial". Although there are thirteen recognized ethnic and national minorities in Hungary, racial profiling 
and racial (ethno-national) conflict predominantly refer to the treatment of a single visible minority, the Roma. The number of immigrants and foreigners with non-European phenotypes is also increasing in recent years, producing a new victim group for racial profiling. Recent immigration however, is still of relatively small scale and mainly transitory. ${ }^{2}$ In fact, immigrants make up only about 1,5 percent of the Hungarian population and approximately two third are ethnic Hungarians from coming from the neighboring states.

Although profiling and discrimination in the criminal justice system may exist against Asian, Muslim or other immigrant population, nevertheless, the severity of the disparate treatment of the Roma is exponentially greater. Due to the legal ambiguity of ethno-national classification (see below), the size of the Roma population is hard to establish. Census and academic estimates range between 200000 and $600000 .^{3}$

\section{Group affiliation}

Data collection aside, ethno-national affiliation in itself is a controversial, ardently debated topic in Hungary. Article 68 (1) of the Constitution states: national and ethnic minorities living in the Republic of Hungary participate in the sovereign power of the people: they represent a constituent part of the State. National and ethnic minorities are specifically protected under the Act on the Rights of National and Ethnic Minorities. ${ }^{4}$ The Act does not, however, define the term 'ethnic' or 'national minority'. As a result of political negotiations, for example Jews are not included among national and ethnic minorities for the purposes of the Act, a fact which, however, will not prevent them from being covered by the Race Equality Directive ${ }^{5}$ and general domestic antidiscrimination legislation. ${ }^{6}$

2003 UNHCR Statistical Yearbook Country Data Sheet-Hungary. http://www.unhcr. ch/cgi-bin/texis/vtx/country?iso=hun

3 Census data is inaccurate because many Roma are reluctant to identify themselves as such. Some improvement is noticeable: whereas in the 1991 census 142683 persons declared themselves Roma, in 2001 this number increased to 190 046. Minority organizations put this number somewhere between 400000 and 500 000. The most reliable number was provided by a survey in 1993/1994 estimating 456 000. See UNDP Avoiding the Dependency Trap. Bratislava 2002

4 Act No. 77 of 1993.

5 Directive 2000/43 EC, Official Journal of the European Communities 2000, L 180/22.

${ }^{6}$ Farkas, L.: The Monkey that does not see, Roma Rights Quarterly, 2004. No. 2. rhttp://www.errc.org/cikk.php?cikk=1940 
The 1993 Act defines national and ethnic minorities as groups which have been present in the territory of Hungary for over 100 years and „(\$ 1.) constitute a numerical minority within the population of the country, whose members hold Hungarian citizenship and differ from the rest of the population in terms of their own tongue, cultures and traditions, and who prove to be aware of the cohesion, national or ethnic, which is to aim at preserving all these and at articulating and safeguarding the interests of their respective historically developed communities." According to the Act, these minorities are: Bulgarian, Roma (Gypsy), Greek, Croat, Polish, German, Armenian, Roman, Ruthenian, Serb, Slovak, Slovene, and Ukrainian; and in order to register a new minority group, a popular initiative signed by 1000 citizens has to be submitted to the Speaker of the Parliament. The Act also provides for the (fundamental) right of self identification and lays down specific protections for minorities' members, including the prohibition of any policy that "persecutes a national or ethnic minority or any of its members because of their national status, makes their living conditions more difficult, or prevents them from exercising their rights".

Without going into an in-depth analysis of the Hungarian statutory model, two controversies-procedural as well as material-need to be pointed out. Both material requirements (100-year presence and 1000 signatures as a special popular initiative) for qualifying as an ethnic or national minority seem problematic. The Act, besides defining the two group constituting requirements, also contains an enumeration of the thirteen minority groups that are recognized by the Act, which means that the Parliament will actually need to pass a formal amendment to these provisions if a new group would qualify. The House (being sovereign) however, is not obliged to vote affirmatively on the question, which is in sharp contradiction with the otherwise clearly defined requirements. ${ }^{7}$

Another set of issues concern the question of is who is to verify or question whether the 100-year requirement has been fulfilled, and when is the clock supposed to start ticking. When will the Chinese minority (a considerable population since the political transition) be entitled to seek recognition? What about the Palestinians, who may claim some 600 hundred years of presence if „Ismaelite" merchants are considered?

7 A number of Parliamentary and Constitutional Court decisions have been passed on petitions of various ethno-national groups, like the Jews, Aegean Macedons, Russians, the Bunyevac, or Huns seeking recognition.

${ }^{8}$ Both groups have estimated numbers of 10000 . Meanwhile some doubt that certain recognized minorities (such as the Ruthenian for example) have fulfilled the statutory numerical requirements. (The same doubts were raised on that of the 100 -year presence of 
As a background note, it is important to stress that post-1989 Hungarian minority-politics cannot be understood outside the context of the ethnic Hungarian Diaspora. (Following the Treaty of Trianon in 1920 two-third of Hungary's historic territory (with a corresponding population) had been annexed to the neighboring state. Since then, but especially after the 1989 political transition, Diaspora politics has been a dominant factor in Hungarian foreign and domestic politics.) We can even say that besides classical commitments, one of the primary reasons behind constitutional motivations for providing and recognizing minority rights had been Article 6 (3) of the constitution, which declares that "the Republic of Hungary bears a sense of responsibility for the fate of Hungarians living outside its borders and shall promote and foster their relations with Hungary." Commentators ${ }^{9}$ claim that the creation of the above described homogenous legislation for national and ethnic minorities may help promoting rights of ethnic Hungarians in the neighboring countries; it cannot, however, provide an effective institutional framework to deal with the specific and robust Roma-problem. Also, this monolithic minority category is inefficient in serving the needs of all thirteen official minority groups in Hungary, which substantially differ in size and consequent claims and aspirations. Also, critics point out ${ }^{10}$ that the European accession and subsequent changes in the constitutional and socio-political climate will bring challenges that the anachronistic, pre-accession minded Diaspora-targeting law cannot cope with. For example, the appearance of European or other migrant workers and immigrants will bring challenges that the existing legal framework may not be able to handle. Newly arriving groups will easily outnumber small traditional national minorities (such as the Armenian and Ruthenian), while the current legal framework does not have clear guidelines as to how new groups can seek official recognition.

the Greeks.) The legislator is of course free to recognize any group as a national or ethic minority (even lacking the general conditions), yet the statutory language setting forth the requirements therefore seems absolute and general, and is thus somewhat misleading.

9 See for example, Pap A. L.: Minority Rights and Diaspora Claims: Collision and Interdependence. In: The Status Law Syndrome: Post-Communist Nation-Building or Post-Modern Citizenship? Hokkaido University, Sapporo, 2005. (forthcoming).

${ }^{10}$ See for example, Pap A. L.: Csatlakozás és csalatkozás. A kisebbségi törvény módosításának kihívásai és a kormány modellje (Accession and Disillusionment: Challenges Facing the Government's Model for Amending the Act on Ethnic and National Minorities). http://www.nfh.hu/index 2.htm?p=2\&t=2\&i=2967 


\section{Individual affiliation}

The other, even more controversial element of the Hungarian framework relates to the lack of satisfying legal guarantees regarding individuals' minority affiliation. Hungarian law allows for the handling of data on racial and ethnic origin only with the consent of the person concerned. ${ }^{11}$ This gives rise to what is commonly known as "ethno-business" or "ethno-corruption", that is, the utilization and misusage of remedial measures for private means that are contrary to the legislators' intentions.

In this model, the exercise of minority rights is not dependent on minimal affiliation requirements. For example, Stephen Deets documents how school officials pressure parents of 'Hungarian' students to declare their children 'German': ,according to Hungarian government statistics, in 1998, almost 45000 primary school students were enrolled in German-minority programs, which, by the latest census, is about 8000 more than the number of ethnic Germans who are even in Hungary." 12

Hungary also established a relatively potent form of autonomous minority institution, the 'minority self-government' structure (bodies that co-exist with local municipal administration), and the decision to vote at these elections was left solely to the political culture and conscience of the majority. Thus, in Hungary, citizens, regardless of their ethnic origin, could vote for minority self-government candidates. This enabled members of the majority to take advantage of the various remedial measures. For example, the wife of the mayor of Jászladány-a village notorious for segregating Roma primary school children from non-Roma-held an elected office in the local Roma minority self-government. Likewise, non-Romani parents can claim that they are Romani in order to conceal racial segregation. ${ }^{13}$

Hungarian minority representatives repeatedly claim that the fact that some candidates ran as 'Gypsies' in one election and then later as Germans in the following term (which is permitted by both the law and the ideal of multiple

${ }^{11}$ This of course does not prohibit the anonymous collection of census data. In general, Articles 2(2) and 3(2) of Act No. 63 of 1992 on the protection of personal data and the publicity of public data (Data protection Act).

${ }^{12}$ Deets S. Reconsidering East European Minority Policy: Liberal Theory and European Norms. East European Politics and Society 16 (2002).

${ }^{13}$ For a detailed case description see Roma Rights 2003. 107-108. In the summer of 2003 the Roma Press Center's fact finding revealed that at one point non-Romani parents signed a petition in which they too claimed to be Romani. 
identity-formation) proves the flourishing of local ethno-business. ${ }^{14}$ Similarly, both the President of the National Romanian Minority Self-Government ${ }^{15}$ in Hungary and the (Romanian) Secretary for Romanians Living Outside Romania ${ }^{16}$ found it worrisome that the 2002 local elections brought an increasing number of candidates for Romanian minority self governments, while the number of those identifying themselves as Romanian in the national census is decreasing. ${ }^{17}$ In their view, the answer lies in the fact that "Gypsies" and Hungarian immigrants who moved from Romania are running as Romanians. In order to demonstrate the fallacies of the legal framework, some Roma politicians publicly decided to run under different labels (in most of the reported 17 cases, Slovakian). Also, there are several municipalities where (according to the national census) nobody identified herself as a member of any minority group, yet numerous minority candidates were registered. ${ }^{18}$

Though there are no exact data on the number of minorities of Hungary, based on the number of votes cast at minority-self-government elections it can be safely claimed that a significant number of citizens, who are not members of any minority, voted for minority candidates. ${ }^{19}$ (At the 2001 census, 139763 persons, that is $1,37 \%$ of the population, claimed to have a minority language as their mother tongue-the census made it possible for everyone to mark maximum three languages. Three answers could be given concerning nationality affiliation as well-318 391 persons acknowledged belonging to some minority, constituting $3,12 \%$ of the population. In light of this evidence, it is interesting to note that 1777299 person in the first election in 1990 and 2657722 persons in the second one in 1994 cast their vote for some minority candidate.)

\footnotetext{
${ }^{14}$ See the minority-ombudsman's annual parliamentary reports or an interview with Antal Heizler, President of the Office for National and Ethnic Minorities, Népszabadság (the leading Hungarian daily), 2002. 07. 24.

${ }^{15}$ The President did not predict that more then 7 out of the 17 local self-governments running in the 2002 elections in Budapest (and some 30 out of the 48 registered nationally) would be "authentic Romanian". Out of the 13 local Romanian minority self-governments operating between 1998 and 2002, he estimated that only three have "real Romanian blood" running in their veins. See the summary of an interview with Kreszta Trajan, Népszabadság, 2002. 08. 21.

${ }^{16}$ See the statement of Doru Vasile Ionescu in Népszabadság, 2002. 08. 15.

${ }^{17}$ Only five signatures are needed for the registration of a minority self-government. (For which subsequently everybody, including members of the 'majority', may vote.)

${ }^{18}$ See Népszabadság, 2002. 08. 15.

${ }^{19}$ Majtényi, B.: Minority Rights in Hungary and the Situation of the Roma. Acta Juridica Hungarica 45 (2004) 131-148.
} 
The examples of loopholes in the legal regime sometimes result in complete absurdity. In order to express their admiration of German football for example, a small village's entire football-team registered as German minority-candidates for the elections. ${ }^{20}$

It should also be noted that the question of ethno-national identity has been the focus of other socio-political debates, such as the Hungarian status law, a framework legislation that provides for schemes of rights and preferences available for ethnic Hungarians living in Diaspora. During the drafting of this law, ${ }^{21}$ an ardent domestic political debate ${ }^{22}$ arose from the various legislative approaches in identifying who would be considered Hungarian (for the purposes of the law.) In fact, the contradiction between the basic liberal tenet of the free choice of identity and the desire to reduce (the legal) options for both politically and financially undesirable misusage was perhaps the most controversial aspect of the law.

In June 2005 the Hungarian Parliament passed ${ }^{23}$ a comprehensive amendment to the Minorities Act. The legislation made it a point to set forth a plan for institutional reorganization of the minority-protection mechanisms. At the same time, combating the aforementioned ethno-corruption, it introduced a somewhat controversial registration procedure for those who decide to take advantage of the various privileges and additional rights set forth by the minority law. In order to ensure that only members of the given minority can vote and be elected to minority self-government, the law redefines the meaning of Article 68. par. (4) of the Hungarian Constitution which stipulates that national and ethnic minorities have the right to establish minority self-governments. The Act thus departs from the preexisting dedication to the free choice

${ }^{20}$ Interview with Mr. Heizler, Id.

${ }^{21}$ Act 67 of 2001 .

${ }^{22}$ Two of the three opposition parties in parliament have severely criticized the text, claiming first of all that the government is significantly underestimating the cost of the law. The Socialist party estimated that as many as one million people would be taking advantage of the health care benefit, which alone could cost around 15 billion Forints $(\$ 50$ million), and the annual price of the proposed legislation would actually add up to around 60 billion Forints. Additional concerns were raised regarding the labor market's capacity to deal with the estimated additional 700000 legal laborers. Opposition liberals expressed grave misgivings about the overall conception behind the law, claiming that the intricate web of preferences and benefits (most of which would be available in Hungary) does not support staying but in fact encourages immigration.

${ }^{23}$ The President vetoed the legislation and the Constitutional Court struck down some of its provisions. 
of identity and by eliminating the explicit provision allowing for the recognition of multiple identity, sets forth legal requirements for minority political participation. According to the new legislation, ${ }^{24}$ both the right to vote for and to run as candidates at the minority elections would require the registration. ${ }^{25}$ The first minority self-government elections under the new regulations will be held in autumn 2006.

Having described general issues relating to ethno-national identity, let us now turn to the question of ethnic data collection.

\section{Ethnicity and Data Collection}

As mentioned previously, data protection laws in Hungary, in particular Articles 2(2) and 3(2) of Act No. 63 of 1992 prohibit the handling of sensitive data, such as ethnic origin, without the concerned person's explicit permission. Sometimes practice in this area appears to be quite illogical. For example, officials claim that the recording of racial violence victims would run against statutory provisions, even though the Criminal Code acknowledges certain racially motivated crimes, ${ }^{26}$ such as "violence against members of national, ethnic or racial minorities and religious groups" or "incitement against community", all of which presuppose membership in the given (racially or ethno-nationally defined) community. Although on the national level, the existence of such statistics is mostly denied, ethnic data is collected by many institutions-for administering minority self government elections, affirmative action quotas, minority scholarships, etc. ${ }^{27}$ For some procedures set forth by the Minorities Act (seeking minority self-government elections or minority language education, registering first names that are not included in the official Hungarian register, etc.) one needs to make a formal declaration regarding ethno-national affiliation in order to be eligible for the measures or preferences.

${ }^{24}$ Act CXIV. of 2005.

${ }^{25}$ See for example Minelres News, Office for National and Ethnic Minorities, Budapest, Hungary, Selection of news on national and ethnic minorities in Hungary, March 2004, http://lists.delfi.lv/pipermail/minelres/2004-March/date.html.

${ }^{26}$ The Hungarian Criminal Code (Act IV. of 1978) criminalizes four types of behavior that may fall under the racially motivated category. These are: genocide (Article 155), apartheid (Article 157), violence against members of national, ethnic or racial minorities and religious groups (Article 174/B) and incitement against community (Article 269).

${ }^{27}$ For more, see Farkas: op. cit. 
It should also be stressed that the anonymous collection of data relating to one's perceived ethnic origin for research purposes is not explicitly prohibited by the Data Protection Act, since it defines sensitive data as one that relates to racial origin, national and ethnic minority affiliation-not perceived racial origin. For example, the Hungarian Helsinki Committee's research into discrimination against Roma defendants in the criminal justice system (see below) was too based on perceived ethnic origin.

This leads us to the central question within ethno-national data collection (and similarly, within racial profiling and discrimination): whether group identity should be based on self-identification, or on perception. ${ }^{28}$ As Lilla Farkas $(2004)^{29}$ claims,

"Perceived ethnic origin and self-identity are rather different notions, the former being an objective category, and the latter a subjective one. Neither can be established with indisputable certainty, as there will always be, for example, Roma who bear less visible signs of their ethnicity. On the same token, persons identified by the majority as being Roma may deny affiliation with this ethnic group on account of having lost cultural and language links with the group.."

Curiously, the case law pertaining to penalizing 'violence against a member of an ethnic group' ${ }^{30}$ suggests that Hungarian criminal law recognizes the difference between self-identification and perceived ethnic origin and attaches the same criminal liability to violence committed on either ground. As Hungarian judges seem to understand now, a plaintiff who does not profess herself in court as belonging to the Romani minority, can at the same time claim that he was discriminated on the ground of her perceived ethnic origin. It is in fact the perception of Romani ethnicity and not self-identification that establishes the ground of discrimination. ${ }^{31}$

In general, as Farkas (2004) points out, with Hungarian law allowing for the handling of data on racial and ethnic origin only with the consent of the person concerned, the effect is a severe impediment on the prospect of litigation

\footnotetext{
${ }^{28}$ Two major camps fight in social sciences, those in favor of self-identity, such as János Ladányi and those in favor of perception, such as Gábor Havas, István Kemény and Gábor Kertesi. Farkas: op. cit.

${ }^{29}$ Id.

${ }^{30}$ Article 174/B of Act 4 of 1978 on the Criminal Code.

${ }^{31}$ See Farkas: op. cit.
} 
against indirect discrimination or institutional racism. ${ }^{32}$ Furthermore, as mentioned above, the law gave rise to what is commonly known as "ethnobusiness" or "ethno-corruption", especially in relation to participation in minority elections and election of minority self-governments. Finally, the law diminishes hopes to devise or implement positive action programs. As the European Commission against Racism and Intolerance (ECRI) reported in 1999: "while acknowledging the fact that the collection and utilization of data on ethnic origin is restricted in Hungary for valid reasons, ECRI is concerned that the lack of reliable information about the situation of various minority groups living in the country makes evaluation of the extent of possible discrimination against them or the effect of the actions intended to fight such discrimination difficult." ${ }^{33}$

The two aforementioned Acts (on minority rights and data protection) created two specialized Commissioners to insure that data protection, informational privacy and access to public data, as well as minorities' rights are respected. The two ombudsmen play a crucial role in framing a workable racial profiling policy and safeguarding the handling of ethnicity-related data.

\section{Criminal Justice and Ethnic Data}

Having demonstrated the controversial nature of the Hungarian legislative approach to ethnic data collection in general, in the following sections, the paper will scrutinize its consequences with respect to criminal justice. Criminal investigation and law enforcement practices provide another source of evidence for proving that the denial to recognize ethnicity in a system which nevertheless (formally, or informally) takes it into consideration is not a good policy. This thesis will be supported by two examples: first, the analysis of policing and indicting racially motivated crime, and second, the question of police ethnic profiling. In reference to the first question, the paper will argue that law

\footnotetext{
${ }^{32}$ Under Article 19(1) b, of Act No. 125 of 2003 on equal treatment and the promotion of equal opportunities the plaintiff must establish his ethnic origin in order for the burden of proof to be reversed. In any case, under Article 8 protection is based on ethnicity, thus he must clear this issue when bringing a case. In cases of indirect discrimination not only the ethnicity of the plaintiff(s) but also of the comparator(s) must be established. The latter may prove an insurmountable task.

${ }^{33}$ Second report on Hungary, Adopted on 18 June 1999 made public on 21 March 2000, Para. 26. http://www.coe.int/T/E/human_rights/Ecri/5-Archives/1-ECRI's_work/5CBC_Second_reports/Hungary_CBC_2.asp
} 
enforcement agents, as well as prosecutors and courts, are very reluctant to recognize racial motivation in violent and non-violent crimes.

\section{Ethnic data and race crimes}

Notwithstanding the sweetest sounding constitutional and statutory languages on equal treatment, free choice of identity and the protection of sensitive data, it is always the discriminatory practice of the majority that will actually provide a practical definition for ethnic affiliation. Thus when it comes to the maltreatment of members of various ethnic groups, no difficulties in definitions arises for the discriminating party. Such conceptual ambiguities will only worsen the protections provided for the victimized group. Consider for example the case of racially motivated crimes.

The Hungarian Criminal Code (Act IV. of 1978) criminalizes four types of behavior that may fall under the racially motivated category. (Racial motivation is implied in the wording of the law.) These are: genocide (Article 155), apartheid (Article 157), violence against members of national, ethnic or racial minorities and religious groups (Article 174/B) and incitement against community (Article 269). Nevertheless, it is safe to say that the first two never, and the latter two only very rarely occur in official statistics.

For example, in the past five years, no investigation was initiated in relation of apartheid or genocide, whereas the statistics for Article 269 and 174/B are as follows: ${ }^{34}$

Table 1. shows the statistics for investigations and charges brought under "violence against a member of a national, ethnic, racial or religious group" (Penal Code, Article 174/B) offences.

\begin{tabular}{|c|c|c|c|}
\hline year & $\begin{array}{c}\text { cases } \\
\text { identified }\end{array}$ & $\begin{array}{c}\text { offenders } \\
\text { identified }\end{array}$ & $\begin{array}{c}\text { charges } \\
\text { brought }\end{array}$ \\
\hline 2001 & 12 & 9 & 9 \\
\hline 2002 & 5 & 5 & 5 \\
\hline 2003 & 11 & 9 & 8 \\
\hline 2004 & 7 & 6 & 5 \\
\hline 2005 & 7 & 3 & 2 \\
\hline
\end{tabular}

\footnotetext{
${ }^{34}$ Information provided by Chief Prosecutor's Office to the Hungarian NFP.
} 
Table 2. shows the statistics for investigations and charges brought under "incitement against community" (Penal Code Article 269) offences.

\begin{tabular}{|c|c|c|c|}
\hline year & $\begin{array}{c}\text { cases } \\
\text { identified }\end{array}$ & $\begin{array}{c}\text { offenders } \\
\text { identified }\end{array}$ & $\begin{array}{c}\text { charges } \\
\text { brought }\end{array}$ \\
\hline 2000 & 5 & 1 & 1 \\
\hline 2001 & 10 & 12 & 11 \\
\hline 2002 & 13 & 11 & 11 \\
\hline 2003 & 14 & 11 & 11 \\
\hline 2004 & 17 & 1 & 1 \\
\hline 2005 & 4 & 1 & 1 \\
\hline
\end{tabular}

This should by no means imply that racial crimes and violence are nonexistent in Hungary, but rather that law enforcement agents, as well as prosecutors and courts, are very reluctant to recognize racial motivation in violent and non-violent crimes committed against Roma and other minority victims. Although officers and officials habitually claim that it is because of the lack of clear legislative guidelines for the establishment of racial motivation that most of such instances will only qualify as nuisance, assault or mischief. On the other hand, many politicians and experts argue that criminal legislation in force could easily allow for a less narrow, more minority-friendly interpretation.

In Hungary, in line with the legally articulated declaration to refrain from any kind of involuntary official classification of ethnicity, no specific legally binding instructions exist for the determination of racially motivated criminal activity. Thus, law enforcement officers, who are the prime decision-makers as to the legal classification of a given offense will follow the easier way, and become very reluctant to classify incidents, conflicts as racially motivated. Although it will always be the law-school-graduate prosecutor who will decide on what grounds to indict the defendant, she will usually follow the police's determination on the nature of the criminal offense in question. As for the police, officers claim that in determining whether an offense is racially motivated, they take notice of an internal guidance issued by the Attorney General that directs prosecutors when considering and qualifying the indictment. This means that the only legal guidance is an internal policy guide, which, needless to say, would not stand very strong against constitutional challenges. The outcome is clear: in order to avoid making an uncomfortable and (given the widespread anti-Roma or xenophobic sentiments in Hungarian society) unpopular decision, and lacking any legally binding guidance, we 
see a very strong reluctance to recognize racial motivation in violent criminal behavior.

As noted above, this practice also seems quite illogical at times, for example in the case of race crime victims. Referring to data protection regulations, official statistics have no reliable data on the ethnicity of race crime victims, either, which is entirely absurd, given that the existence of racially motivated crimes logically presupposes membership in the given (racially or ethno-nationally defined) community. Other evidence for demonstrating that such a narrow interpretation of a facially minority-friendly principle is actually contrary to the victimized groups' interest, is that the above mentioned criminal statistics operate with a homogenous victim category, and statistics will not contain figures broken up into the various protected categories (racial, national, ethnic, religious groups). This will make it very difficult for minority representatives or advocacy groups to demonstrate their case.

\section{Police Profiling and Ethnic Data}

In this section, the paper turns to the assessment of ethnic profiling in police work. Scrutiny of ethnic bias in policing and criminal justice should ideally include all of the following: stops and searches, detaining, arrest, criminal procedure, charging, sentencing, disparity in police brutality, access to counsel, law enforcement public employment, ineffective legal remedies, expulsion and immigrant treatment. Due to spatial limitations, the analysis of all these issues is not possible in this article. Consequently, this last part will only cover ethnonational data processing in police stop and search, and within that framework, vehicle stop and search procedures in particular. The paper's aim is to provide an overview of what type of ethno-national (racial) data is and may be collected in Hungary, how and where it is stored, and who has access to it.

This section is based on a field research that was commissioned in 2004 by the Hungarian Helsinki Committee and the Open Society Justice Initiative. ${ }^{35}$ The research is part of a comparative study that involves a number of countries and focuses on 'Addressing Racial Profiling and Discrimination in Policing'.

\footnotetext{
${ }^{35}$ See http://www.justiceinitiative.org
} 


\section{Stop and search powers}

According to the Hungarian legal framework, the police may stop anyone at any time and ask questions it deems necessary. ${ }^{36}$ The vacuous language of Article 29 of the Act on Police ${ }^{37}$ gives full authorization for the police to stop and ask for identification 'anyone, whose identity needs to be established.' If need comes, because the individual is not willing to cooperate or her identity cannot be sufficiently established, she may be searched, ${ }^{38}$ can be arrested ${ }^{39}$ and be held for eight hours, which, if the process has not been successful, can be prolonged for an additional four hours by the chief of the local police unit. Should this (maximum 12 hour) arrest not be sufficient, another type of detention $^{40}$ ("public order detention") may be ordered, which (including the time spent in arrest) may take as long as twenty-four hours. For these stop and search procedures no suspicion whatsoever is needed, no probable cause standards are set forth and unsuccessful identification itself may lead to up to 24 hours of detention. Apart from arrests or detentions, the police are under no obligation to provide an explanation-the only exception being when the individual herself requests such information. ${ }^{41}$ The Constitutional Court ruled on several challenges to these provisions, ${ }^{42}$ and has been consistently dismissing petitioners' claims, despite dissents pointing to the disproportionate length of the detention and the lack of motivation for speedy police procedures involving detainees who are being held without having committed anything illegal.

Another form of stop and search competences comes up in the context of vehicle control. According to Article 44 of the Police Act, the police may at any time check the legality of vehicle operation and possession. The police may therefore randomly stop and check vehicle ownership documents, certificates for appropriate carbon-dioxide emission, motorway passes, they may check the first-aid kit (a required accessory for all vehicles), the insurance contract leaflet of the vehicle, or the condition of the windshield wiper. Critics ${ }^{43}$ have

${ }^{36}$ Article 32. of the Police Act.

${ }^{37}$ Act 34. of 1994.

${ }^{38}$ Article 29.

${ }^{39}$ Article 33 .

${ }^{40}$ Article 38 .

${ }^{41}$ Articles 29 and 33.

${ }^{42}$ Decisions No. 9/2004. and 65/2003.

${ }^{43}$ See for example, Pap, A. L.: "Street Police Corruption-A Post-communist State of the Art", Kokkalis Program on Southeastern and East-Central Europe, Kennedy School of 
argued that it raises constitutional concerns that a significant part of this type of control is actually of an administrative nature and should not be performed by the police forces. For instance, in the case of a company car, checking the authorization from the manager is not a matter of policing per se, but serves social security, tax, and administrative purposes instead.

Police competences raise another problematic point: the issue of reasonable suspicion and probable cause standards. According to the Act on Criminal Procedure $^{44}$ probable cause is needed for the initiation a criminal procedure; still, an arrest or the above mentioned "public order detention" does not qualify as such. As a result, apart from failure of proper identification, a "simple" suspicion (the probability of criminal offence does not exceed 50 percent) also suffices for these coercive measures. ${ }^{45}$ Although the legislator never cared to explain what these standards are supposed to mean, the Constitutional Court upheld the law, ${ }^{46}$ precisely on the ground that these measures do not amount to criminal procedure and the detained (whose cooperation is crucial in these procedures) does not qualify as a defendant under criminal procedures.

\section{Data processing $^{47}$}

Turning to the question of actual data processing, based to the field work that had been carried under the auspices of the above mentioned research project, it may be established that police data collection and reporting is done on two levels: paper forms filled out on the spot and the Robocop 2000, an integrated computerized system that is only accessible in the police office. Apart from

\footnotetext{
Government, Harvard University, http://www.ksg.harvard.edu/kokkalis/GSW3/Andras_ Laszo.pdf

${ }^{44}$ Act 19 of 1998 .

${ }^{45}$ Article 33.

${ }^{46}$ Decision no. $65 / 2003$.

${ }^{47}$ This subsection is based on informal interviews and consultations with the following: Captain Tibor Jármy, Ministry of Interior; Szilveszter Póczik, Senior Associate, OKRI, National Institute of Criminology; István Vavró, Department Head, Ministry of Justice; Ferencné Horváth, Attorney General's Office; Klára Csányi, Department Head, Ministry of Interior; István Lóczy, Department Head, Ministry of Interior; Major Szabolcs Szovics, Budapest Police; Captain László Inárcsi, Department Head, Mezokovesd Police; Captain Nagy Zsolt, Department Head, Sátoraljaújhely Police; Liutenant Colonel Zoltán Klima, Department Head, National Police; Gábor Tarján, Associate Professor, Police Academy, Budapest; Colonel Mihály Szabó, Director, National Police; Colonel Tivadar Dormán, Department Head, National Police; Major Eva Ecet, Ministry of Interior.
} 
sporadic usage of computerized vehicle recognition systems (by mostly specialized units) in-car computers or other handheld computer devices are unknown to Hungarian police officers, thus communication mostly is done via radio with the dispatcher. ${ }^{48}$

The first type of data gathering is done on the spot, during stops and searches. In theory, officers would have to report and register every performed activity, regardless of whether they will actually initiate any further criminal or other procedures. The somewhat dubious language of Article 32 of the Internal Minister's Decree on Police Conduct ${ }^{49}$ sets forth that the police officer has to fill out a registration form (a so called "RK" form-none of the interviewed officers knew what the abbreviation stood for) in case of identifying someone, and also if further procedures or other circumstances deem it necessary. Data gathering thus may be extended to other people, such as passengers of the vehicle. Presumably, the mandatory registration of all police stops and activities serves internal activity-reporting purposes. From the informal interviews I made, I gathered that (although not always) in most cases, the forms are filled out even in case nothing extraordinary or illegal has been detected.

The form, filled out on the spot by the officer, contains the following data: name; date of birth; mother's maiden name; address; ID card number, expiration date; place, time and reason of stopping; description of the activity that the police action follows; name, rank of the officer. In case of vehicle control: license plate number, type of vehicle, vehicle registration document number, expiration date, owner's name, address. If offenders are being fined on the spot, there is no need to fill out the form, penalty-documentations suffice. The actual form is somewhat anachronistic, bearing a strong reminiscence to communist totalitarianism; it contains several questions that are no longer being asked, such as marital status, number of children, workplace, monthly salary.

The second type of data processing takes the form of a national computerized database, the integrated Robocop ${ }^{50}$ (Robotzsaru) 2000. According to a National Police Chief's Order, ${ }^{51}$ all relevant data in criminal proceedings need to be

${ }^{48}$ Interestingly, the data protection ombudsman expressed concerns about the transmitting of sensitive, personal data via the radio, because it sometimes enables unwarranted bystanders to overhear information that should not be disclosed. Therefore the police promised to take due care of the situation...

${ }^{49}$ 3/1995 (III.1.) BM rendelet (Decree of the Internal Minister).

${ }^{50}$ The program actually bears an image from the 1987 motion picture Robocop.

${ }^{51}$ Orders of the Chief of the National Police (Orfk intézkedés) 22/2000 (XII 29) and 1/2003 (II. 12). 
registered in the database. In Article 5/b, the relevant data category is defined to include all data pertaining to stops, searches, arrests, reports, complaints and denunciations. This means that all data registered in the "RK" forms will be entered into the Robocop and the forms will be destroyed.

As mentioned above, no police registry contains any ethno-national or racial data per se. In official use, such as press releases for example, even if the victim or a witness would claim that the offender was, say, Roma, the formal suspect description will not use any ethno-national signifiers. The overwhelming majority of police officers I informally interviewed claimed that there is no ethnic data at all in any of the police registries. The commissioned research however proves this to be not entirely the case. There are two ways ethno-national or racial data may be processed in police documents: within testimonies by victim defendant or witness, and in the aforementioned Robocop informational network. Curiously, while most high-ranking ministerial officials denied it, field officers and detectives admitted that in case the victim, a witness, or the offender/defendant in his/her testimony or report will claim someone to be, say, Roma, and if they insist on this statement to appear in the records, such data will be a registered and filed as part of the case documentation (and similarly to all important statements, will be attached to the case-file and entered into the Robocop.)

Therefore if the victim were to state that the offender was "presumably Roma", it would actually be part of the case files. Some officials were of the opinion that this would only be the case if the person herself had claimed that she was a member of the minority. It has been the researchers' overall opinion that, although in informal communication anti-Roma racism is almost universal within the force, officers are quite uncomfortable using ethno-racial classification in any form of formal communication, be it verbal (such as orders given by the superiors) or written and (out of fear from political attacks) will tiptoe around it and use a (presumably) politically correct meta-language instead. In sum, officers are unlikely to ask direct questions pertaining to ethnicity, and as far as the records are concerned, may even try to persuade witnesses and victims to avoid using, say, the term 'Roma'.

The other way ethno-racial data may appear in police registries is even more intriguing. The aforementioned Robocop is not only an integrated database, but it is also the basis for a unified police-prosecutorial statistical database. This is a DOS-based computer program where all information is being stored. Most of the data is entered through a code-system, thus the officers and the detectives are only selecting among pre-established options. The registry has chapters on the offense and the offender. The database provides a thorough 
analysis of the case and the suspects/defendants and also has a detailed listing of causal factors which are divided into "objective" and "subjective" ones. "Objective factors" would include "covering for other criminal offenses", "problems in the family or school", "low income", "dropping out from school", "alcoholic or criminal family background", etc. "Subjective factors" may include "lack of driving experience", "tiredness", "emotional distress", "criminal past", "bad influence from peers", "antisocial attitudes" and somewhat anachronistic concepts like "bad media influence", "selfishness" or "seize the day-attitude". ${ }^{53}$

The database has a similarly detailed method for describing the appearance of the suspect/defendant. In the codebook we find a set of personal characteristics like the form and size of the ears and the teeth, "hollow cheeks", "raspy voice", "tattoos", "meeting eyebrows", "deformity and maiming". Among these identifiers I came across two types that contained ethno-racial references. The first type I found among the set of options provided for describing facial skin and complexion (among others like "blotchy or pockmarked face"): "Romalooking", "Creole", and "Arabic, Negro ${ }^{54}$ Asian" (sic). Also, among the options provided for "accents or dialects" I found the following categories: "with a Roma accent" "wailing ( sic) like a Roma". ${ }^{5}$

These ethno-racial classifications are made by the officer/detective, thus in the overwhelming majority of cases, the classification is not based on selfidentification, but on an outsider's perception. Ironically, one of the officers I interviewed said that he would actually let the defendant/suspect decide how she would be categorized: 'Roma' or 'Creole'. As mentioned above, all these factors are listed and the officer can only choose from the pre-established options and will only type in the appropriate code number. It is important to point out that the officers do not have to fill out all the questions; it is entirely up to their discretion. Furthermore, at the end of each section, there is an "other" category, where (unlike the previous ones) the officer can type in whatever she may consider relevant. In theory, this could even include victims' or witnesses' statement regarding the offender's ethnicity. In general, it is safe

${ }^{52}$ Section 39 of the database is now eliminated; it used to contain the explicit question whether or not the defendant/suspect is Roma.

${ }^{53}$ Officers are very reluctant to find a crime to be racially motivated, even though they could do so (see above).

${ }^{54}$ In the Hungarian socio-linguistic context the term "Negro" is not necessarily pejorative. (Legislators, drafters and webmasters of such a database on the other hand should have been aware of the international context...)

${ }^{55}$ In Hungarian: “cigányosan sápítozva”. 
to say, that such a scenario is quite unlikely - partly due to the aforementioned uneasiness about dealing with ethno-racial data in official communications and also in part because of the fact that this would mean additional work. As I gathered from the interviews, officers do not like to waste their time thoroughly filling out the causal factors section. Access to data depends on the status and position of the officers, as well as their standing (level and degree of involvement) in the procedure. One may have the impression, that it is only due to the lack of sophistication of the IT-system that ethno-national data is not easily accessible or connected to other data.

\section{Data processing and ethnic profiling}

Intriguing as findings within the previous section were, the consequences are dubious. As we have seen, data processing is hardly existent in the procedures of the Hungarian police. It would however be an incorrect conclusion to draw that consequently no ethnic profiling or discrimination exists in the criminal justice system. In fact, academic estimates and NGO reports suggest the contrary. Since 1994, maltreatment of the Roma has been widely documented by human rights NGOs such as the Legal Defence Bureau for National and Ethnic Minorities (NEKI), the Hungarian Helsinki Committee (HHC) and the Romani Civil Rights Foundation (RPA). The Parliamentary Commissioner for National and Ethnic Minorities has on numerous occasions called attention to discriminatory police actions towards the Roma. ${ }^{56}$

In 2002-2003, the Hungarian Helsinki Committee carried out research on discrimination against Roma in the criminal justice system, finding deeprunning traces of racial profiling by the police within Roma communities. By scrutinizing court files, the research focused on how perpetrators were initially detected by the authorities. The findings of the survey appeared to be fully in line with similar Anglo-American studies that analyze discrimination in the criminal justice procedure against visible minorities. The researchers found that Roma offenders and suspects were significantly more likely to have been

\footnotetext{
${ }^{56}$ For example, in his 2000 report the Minorities Commissioner observed that the high level of discretion allowed in actions such as house searches may easily allow for ethnic discrimination. In 1999, he reported a complaint filed by a teacher who alleged that his Roma students were discriminated in the course of a stop for ID checks. 2004 saw the first victory of the Hungarian human rights movement engaged in defense of Roma rights before the European Court of Human Rights. For the first time since Hungary ratified the Convention, in the Balogh judgment, the Court found a violation of Article 3.
} 
identified via police stops and searches, whereas in the case of non-minority suspects, other investigatory methods-particularly being caught in the actwere the dominant causes that lead to the suspects' capture. ${ }^{57}$

Another empirical comparative research ${ }^{58}$ conducted on behalf of the Open Society Justice Initiative (OSJI) between 2005 and 2006 indicated that in Hungary the Roma are discriminated against in the context of stops and searches by the police, especially in the practice of stopping pedestrians. ${ }^{59}$ There is strong statistical evidence that Roma are subject to pedestrian stops more often than non-Roma. ${ }^{60}$

Circumstantial evidence from other stages of the criminal procedure also indicates the likeliness of ethnic profiling. According to the 2001 EUMAP report ${ }^{61}$ "research indicates that Roma are more likely than non-Roma to be reprimanded in pre-trial detention or ill-treated by the police, ${ }^{62}$ and tend not to have legal representation during investigation". ECRI has expressed concern

${ }^{57}$ See Farkas: op. cit.

${ }^{58}$ See Pap, A. L.-Simonovits, B.-Balogi, A.-Vargha, L.: Research Report for Hungary, Results from the research project "A Comparative Study of Stop and Search Practices in Bulgaria, Hungary and Spain”, Budapest, 2006.

${ }_{59}$ The research was aimed at examining stop and search procedures by the police. In Hungary, the empirical data collection had four parts: A questionnaire-based public opinion poll targeting a representative group within the Hungarian population; a total of six focus group discussions in Budapest, Miskolc and Pécs, with people-Roma as well as nonRoma-who have experienced stop and search; a total of 20 community interviews in Budapest, Miskolc and Pécs, with people-Roma as well as non-Roma-who have experienced stop and search and a total of 80 interviews in Budapest, Miskolc and Pécs, with officers who conduct stop and search.

${ }^{60}$ The research results are based on a survey series conducted during September, 2005 which shows that over the past year, $23 \%$ of the Hungarian adult population was stopped by the police. Among the Roma respondents 57 percent were stopped as pedestrians, at entertainment venues or some sort of event (a concert, say). By contrast, among non-Roma respondents only 22 percent were stopped at such locations..

${ }^{61}$ EUMAP Monitoring the EU Accession Process: Minority Protection. OSI EU Accession Monitoring Program 2001. 241.

${ }^{62}$ Hungarian Helsinki Committee and OSI-COLPI, Punished Before Sentence, Budapest, 1997. See also UN Committee Against Torture, Conclusions and recommendations concerning Hungary 's third periodic report, November 1998: "The Committee is also concerned about the persistent reports that [...]a disproportionate number of detainees and/or prisoners serving their sentences are Roma." 
"at evidence that severe problems in the administration of justice exist as regards discrimination against members of the Roma/Gypsy community [...]". ${ }^{63}$

\section{Policing and minority-awareness}

In general, racial (ethno-national) awareness in policing is not identified in the context of minority victimization, but rather as a task to reduce Roma-associated criminality. At best, the context of racial (ethno-national) awareness is focused on cultural conflict and equal protection rather than 'race crime. In other words, the important issue in the eyes of police leadership is how to prepare the police force for dealing with the higher criminality rate and cultural specificity of the Roma minority. To put it bluntly, ethnicity is dominantly seen as a problem arising in connection with the offenders and not the victims. Nevertheless, police training encompasses racism in general and racism as a specialized police issue. Anti-discrimination and conflict resolution courses and training are thus incorporated into all levels of police education, which, since 1999 also includes courses in Roma (cultural) studies. We also see a number of special programs promoting Roma presence within the force. There are some (mostly unsuccessful) recruiting programs for the police in Roma high schools, and a number of affirmative action provisions are available for Roma working in the police force. The police also developed nationwide scholarship programs as well as Police Academy entrance examination preparation programs for prospective Roma students.

The police also have a reasonably well developed network of cooperation with NGOs and minority organizations. Human rights organizations operate legal clinics and legal aid programs, and the police organize and participate in training programs in affiliation with civil organizations. Following a 1999 formal agreement between the National Roma Minority Self Government and the National Police, formal and informal connections have been established between local, regional and national level police and Roma minority self governments.

A network of outreach officers and specialized liaisons operate at all levels of police administration, and police leadership annually monitors these networks. Outreach officers and Roma policy-coordinators organize training, crime prevention forums, and sports events (i.e. Roma-Police football games). Although minority self governments are active partners at the level of official declarations, commentators claim that in terms of practical co-operation or

\footnotetext{
${ }^{63}$ ECRI (2000) 5, para. 14.
} 
conflict-resolution, these political bodies are not always fully capable of "representing" the community. In terms of actual policing practice, there are no racial profiling policies per se, but there is an official commitment on behalf of police leadership for providing strict scrutiny to all reports regarding antiRoma discrimination within the force. The Chief of the national police receives an annual report on these cases.

\section{Conclusion}

The foregoing has been an attempt to show one aspect of the legal and social context (the long-standing challenges and sensitivities) of ethnic data generation and collection. It is my conviction that the core question in the Hungarian saga of ethnic profiling and ill-treatment in criminal justice lies in determining under what conditions and with what kind of (external or self-identified) definitions the legal framework should operate. In other words, what serves the minority's interests?

Two contradicting conclusions can be drawn: a modest and a daring one. As for the first, we may confidently state that the Hungarian legislator did not err in providing a narrow framework for ethnic data processing, as whatever the reasons for ethnic profiling and police ill-treatment may be, it is certainly not related to ethno-national data collection. The second conclusion may be that it is (at least partly) due to the lack of applicable tools for measurement that ethnic discrimination may flourish. In other words, maybe it is also due to the superficially satisfying legislative framework for ethnic data collection that indirect and direct discrimination in policing can exist.

The question is far from easy to answer. In fact, it leads us to perplexing long-unresolved dilemmas. The establishment and practical application of legal definitions to complex and abstract human behavioral phenomena is a fundamental and crucial point in the legal hermeneutic process. It is important to note that many legal concepts-such as life or family-are by nature ambiguous; yet when there is legislative and legal interest in providing (legally comprehensible) definitions the legal system is always successful in the creation of some form of conceptualizing. We therefore find workable legal definitions for such complex and otherwise controversial concepts as the beginning of life, or the life of the fetus in relation of inheriting, or family for tax, and civil legal purposes.

The peculiarity of legal conceptualizing lies in the fact that seemingly neutral legal concepts can easily be instruments of social conflict and tools for 
discrimination. For example, a narrow definition of physical disability or mental retardation (phrased in the value-neutral language of medicine) can seriously limit the scope of application of equal opportunity or affirmative action measures ${ }^{64}$ excluding thereby certain groups from its application. ${ }^{65}$ Similarly, throughout the world, one of the terrains of homosexual anti-discrimination legislative lobbying is to loosen up the generic (civil) legal concept of marriage to include same sex partnerships. (Attempts are made at widening the traditional legal marriage-definition, which conceptually requires members to be of the opposite sex.) Ethnic and racial identities are textbook examples for collective representations of socially constructed particular communities. In traditional societies, socially relevant identities (such as class) are usually rigid and unchangeable; it was not until post-feudal, modern, open societies, that there was room left for the individual's free choice of identity and redefined strategic behavior. In fact (at least in theory), in contemporary open societies the denial of free choice of identity equals the non-recognition of the individual as a source of constitutionally protected value, constituting a violation of human dignity. ${ }^{66}$

There are, however, numerous theoretical and practical problems regarding the legal-administrative assessment of ethnic identification. The first inherent contradiction is that while it is membership in an ethnic or racial group that serves as a basis for constitutional protection, it is always the individual who is to be entitled to the special legal regime, benefits or preferential treatment. The practical consequence of administrative-legal attempts to resolve this situation is that the individual's group affiliation is defined either too loosely and ambiguously, or too rigidly. Legislators and the courts are facing at least two types of serious and inherent problems when dealing with affiliation-issues.

The first practical problem of "ethnic cheating" arises in the context of ethnic-racial affiliation being too liberally regulated, or not regulated at all. So the lack of legal and administrative guarantees and restrictions open the

\footnotetext{
${ }^{64}$ Throughout the world, in budget debates there is substantial disagreement about trying to define the medical boundaries of the "disabled group." The issues can be as mundane as why the blind may receive a special state aid while others do not, or why specific social security preferences and benefits do not cover people with diabetes, or nephritis, etc.

${ }^{65}$ For a discussion on whether infertility should be considered a "disability" for the purposes of the Americans with Disabilities Act, for example, see Sato Sh.: A little bit disabled: Infertility and the Americans with Disabilities Act. New York University Journal of Legislative and Public Policy, Vol. 5 No 1. (2001-2002).

${ }^{66}$ For a detailed analysis, see Eisgruber, Ch. L.: The Constitutional Value of Assimilation, 96 Columbia La Review (1996) 87.
} 
possibilities for intentional misusage of measures, policies, or preferences intended for a specific group only. The question arises: what can the state do with the individual's arbitrary, random, or even declared malevolent choice of identity when he or she is seeking preferential treatment? As a matter of law and legal remedies, even if one openly admits to a fraudulent cause for utilizing minority preferences (such as enrolling under minority quotas to educational institutions), there is no legal, political, or even moral basis for questioning such self-identity classification.

The second affiliation-dilemma that law enforcement and legislators need to face is the following phenomenon: notwithstanding constitutional and statutory languages on equal treatment and free choice of identity, it is always the discriminatory practice of the majority that actually provides for de facto usage of affiliation-definition. Thus when it comes to the maltreatment of members of various ethnic groups, no serious definitional or recognition difficulties arise for the discriminating party. Just as (despite the Census Office's multiracial affiliation recognition) a racially profiling American policeman is untroubled by identifying minority drivers, a racist East European restaurant waiter has no qualms about spotting a Roma customer and denying service to her. When it comes to discrimination or ethnic hostility, it is always the daily practice of the majority that will define membership in the discrete and insular minority group.

As for practical solutions, the legislator has basically three options: $a$ ) adopting a formal, in a way exclusive, and to some extent inevitably rigid classification, usually accompanied by some form of registration; or b) accepting the liberal standpoint and leaving ethnic-affiliation selection to the inner, personal and moral decision of the individual; and c) independent of the above two, when it better serves the interest of the underprivileged, victimized group make all its best effort to refer to the perceived, external classification as a rule of thumb.

As mentioned above, underlying this project there are two key dilemmas. The first one regards the question of how ethnicity should be assessed, for example, if we were to advocate that the police start compiling ethnic statistics regarding their patrolling activities: should they make records about perceived or self-claimed identity? The second fundamental question relates to the question of which general data privacy policy serves better the interests of the underprivileged and discriminated minority. That is, whether or not we should encourage a braver and more sincere policy on ethnic data generation or, whether we should instead continue to handle ethnicity as a taboo and see our goal as giving publicity to the potential dangers of allowing law enforcement 
agencies to collect any kind of ethno-racial data. Bearing in mind Justice Harry Blackmun's separate opinion in the cornerstone American affirmative action case Bakke: ${ }^{67}$ „To get beyond racism, we must take account of race ... and ... to treat some persons equally, we must ... treat them differently".

${ }^{67}$ Regents of University of California v. Bakke, (438 US 265, 1978). 